\title{
Kuat Tarik Sambungan Bambu Celah Berpengisi dengan Alat Sambung Baut pada Berbagai Variasi Jarak Ujung
}

\author{
I Wayan Sugiartha ${ }^{1^{*}}$, Aryani Rofaida ${ }^{2}$ \\ ${ }^{1)}{ }^{2)}$ Fakultas Teknik, Universitas Mataram, J1. Majapahit No. 62, Mataram \\ *E-mail: sugiartha88@gmail.com
}

\begin{abstract}
The strength of bamboo connections is one of them determined by the distance of the end of fastener. The distance of the end of fasteneris very important to note on the bamboo connection with the bolt because is tubular and has a low shear strength. The constraint can be overcome by giving the filler oround the connection hole. However, the effectiveness of the filling bamboo that is given a slot to place the knot plates on the connection needs to be further studied. The purpose of this research is to find out the tensile strength of bamboo connections filled with bolt at various variations of end distance and know the connection failure pattern. Five variations of test specimens were made with each end distance of $50 \mathrm{~mm}, 60 \mathrm{~mm}, 70 \mathrm{~mm}, 80 \mathrm{~mm}$ and $90 \mathrm{~mm}$. Testing is carried out at the load frame and loading is gradually supplied through the hydraulic jack until failure occurs. The result show that the tensile strength of the joints increases with the increasing of the end distance of the fastener. The maximum tensile strength produced at $50 \mathrm{~mm}, 60 \mathrm{~mm}, 70 \mathrm{~mm}, 80 \mathrm{~mm}$ dan 90 mmrespectively, end distance variations of $1997,352 \mathrm{Kg}, 2124,36 \mathrm{Kg}, 2336,04 \mathrm{Kg}, 2381,4 \mathrm{Kg}$, and 2411,64 Kg with a percentage increase of $6 \%, 17 \%, 19$ $\%$, and $21 \%$. The pattern of failure on all test specimen is relatively similar to the bolt is buckling or fracture.
\end{abstract}

Keywords: tensile strength, end distance, slot bamboo connection

\begin{abstract}
ABSTRAK
Kekuatan sambungan bambu salah satunya ditentukan oleh jarak ujung alat sambung. Jarak ujung alat sambung sangat penting untuk diperhatikan pada sambungan bambu dengan baut karena bambu yang berbentuk tubular dan mempunyai gaya geser sejajar serat yang rendah. Kendala tersebut dapat diatasi dengan memberi pengisi disekitar lubang sambungan. Namun demikian, efektifitas dari bambu berpengisi yang diberi celah untuk menempatkan pelat buhul pada sambungan perlu dikaji lebih lanjut. Tujuan dari penelitian ini adalah untuk mengetahui kuat tarik sambungan bamboo celah berpengisi dengan alat sambung baut pada berbagai variasi jarak ujung dan mengetahui pola kegagalan sambungan. Lima variasi benda uji dibuat dengan jarak ujung masing-masing sebesar $50 \mathrm{~mm}, 60 \mathrm{~mm}, 70 \mathrm{~mm}, 80 \mathrm{~mm}$ dan $90 \mathrm{~mm}$. Pengujian benda uji dilakukan pada load frame dan pembebanan diberikan secara bertahap melalui hydaulic jack sampai terjadi kegagalan. Hasil pengujian menunjukkan bahwa kuat tarik sambungan meningkat seiring dengan meningkatnya jarak ujung alat sambung. Kuat tarik maksimum yang dihasilkan pada variasi jarak ujung $50 \mathrm{~mm}, 60 \mathrm{~mm}, 70 \mathrm{~mm}, 80 \mathrm{~mm}$ dan $90 \mathrm{~mm}$ berturut-turut sebesar 1997, $352 \mathrm{Kg}, 2124,36 \mathrm{Kg}, 2336,04 \mathrm{Kg}, 2381,4 \mathrm{Kg}$, dan 2411, $64 \mathrm{Kg}$ dengan prosentase kenaikan berkisar sebesar $6 \%, 17 \%, 19 \%$, dan $21 \%$. Pola kegagalan yang terjadi pada seluruh benda uji relatif sama yaitu baut tertekuk atau patah.
\end{abstract}

Kata kunci:kuat tarik, jarak ujung, sambungan bamu celah

\section{PENDAHULUAN}

Aplikasi bamboo sebagai bahan struktur bangunan dapat dimanfaatkan sebagai struktur rangka kuda-kuda. Sementara itu, Bachtiar [2] memanfaatkan bambu untuk konstruksi rangka batang ruang berupa kanopi sederhana berukuran
3 x 4 meter dengan empat tumpuan. Pemanfaatan bambu untuk struktur rangka terkendala pada penyambungannya yang disebabkan karena bentuk bambu yang bulat dan berongga (tubular) dan bamboo mempunyai gaya geser sejajar serat yang rendah. Untuk itu perlu dilakukan upaya untuk meningkatkan kekuatan geser bambu 
tersebut yaitu salah satunya dengan memberi pengisi disekitar sambungan.

Pemberian bahan pengisi dimaksudkan agar gaya yang disalurkan lewat sambungan tidak sepenuhnya dipikul oleh kekuatan geser bambu. Upaya peningkatan kekuatan geser dalam pembuatan sambungan telah dilakukan oleh beberapa peneliti, diantaranya oleh Morisco [5], dimana untuk meningkatkan kekuatan sambungan bamboo digunakan mortar semen atau kayu sebagai pengisi rongga bamboo disekitar sambungan. Marwansyah [4] dalam penelitiannya menggunakan bambu sisa sebagai bahan pengisi pada sambungannya dimana hasilnya menunjukkan bahwa kekuatan sambungan meningkat cukup signifikan dengan pengisi dari bambu sisa tersebut.

Kekuatan sambungan dipengaruhi oleh 3 hal yaitu bahan penyusun sambungan, alat sambung, serta tata letak sambungan yang terdiri dari jarak ujung dan jarak antar alat sambung. Destisari [3] menyatakan bahwa bertambah besarnya diameter baut menghasilkan jarak kritis yang semakin besar pula meskipun perbedaan hasilnya tidak terlalu signifikan. Sementara Saputro [7] pada penelitian sambungan satu baut menunjukkan bahwa semakin besar jarak ujung alat sambung nilai daktilitasnya meningkat. Agar masing-masing alat sambung dapat mencapai tahanan lateral ultimitnya sebelum kayu pecah maka jarak antar alat sambung baut harus direncanakan dan khusus untuk komponen struktur tarik jarak ujung minimum yang diperlukan adalah 7D ( $\mathrm{D}=$ diameter baut), Awaludin [1].

Penelitian-penelitian tentang sambungan yang dilakukan di atas seluruhnya menggunakan double pelat buhul baja dalam mentransfer gaya ke alat sambung baut. Mengingat bamboo berpengisi yang diberi celah dibagian tengahnya untuk memasukkan pelat buhul baja dengan alat sambung baut belum ada yang meneliti maka efektifitas dari model sambungan ini perlu dikaji lebih lanjut. Tujuan dari penelitian ini adalah untuk mengetahui kuat tarik sambungan bamboo celah berpengisi dengan alat sambung baut pada berbagai variasi jarak ujung dan mengetahui pola kegagalan yang terjadi. Benda uji sambungan bamboo celah yang dibuat dengan variasi jarak ujung $50 \mathrm{~mm}, 60 \mathrm{~mm}, 70 \mathrm{~mm}, 80 \mathrm{~mm}$ dan 90 $\mathrm{mm}$. Pengujian benda uji sambungan dilakukan pada load frame dan pembebanan diberikan secara bertahap melalui hydaulic jack sampai terjadi kegagalan.

\section{METODE PENELITIAN \\ BahanPenelitian}

Bambu yang digunakan dalam penelitian ini adalah jenis bamboo galah (Gigantochloaatter) yang diperoleh Kecamatan Gunung Sari Kabupaten Lombok Barat. Bambu yang dipilih memiliki diameter $8-10 \mathrm{~cm}$ pada bagian pangkalnya. Bahan perekat yang digunakan adalah epoksi dengan merk dagang "Union". Sedangkan alat sambung yang digunakan adalah baut dengan diameter $10 \mathrm{~mm}$ dan panjang $15 \mathrm{~cm}$ serta pelat penyambung baja dengan tebal $5 \mathrm{~mm}$.

\section{AlatPenelitian}

Alat-alat yang akan digunakan dalam proses pembuatan benda uji antara lain :gergaji tangan, gergaji mesin, gerinda, parang, sikat kawat dan bor listrik. Perlengkapan untuk proses perekatan seperti kuas, wadah, dan sarung tangan.

Peralatan untuk pengujian antara lain : Universal Testing Machine (UTM), Hydraulic jack, Load cell, TranducerIndicator, Dial gauge, dan Loading frame.

\section{Model Benda Uji Sambungan}

Model sambungan dibuat dari bambu galah berdiameter $8 \mathrm{~cm}-10 \mathrm{~cm}$ dengan panjang 80 $\mathrm{cm}-90 \mathrm{~cm}$ dimana pada bagian tengah terdapat nodia (buku). Kedua rongga bambu diantara nodia diberi pengisi dari sisa potongan bambu yang dimasukkan berturutan sampai mengisi penuh rongga dan masing-masing lapisan direkatkan dengan resin epoxy yang dikempa menggunakan klem baja. Disalah satu ruas dibuat celah selebar $5 \mathrm{~mm}$ dengan panjang sesuai jarak ujung ditambah 3D untuk memasukkan pelat buhul baja kemudian lubang untuk alat sambung baut dibuat dengan variasi jarak ujung 5D, 6D, 7D, 8D, dan 9D ( $\mathrm{D}=$ diameter baut). Dalam hal ini baut yang digunakan dengan diameter $10 \mathrm{~mm}$ sehingga jarak ujung menjadi $50 \mathrm{~mm}, 60 \mathrm{~mm}, 70$ $\mathrm{mm}, 80 \mathrm{~mm}$, dan $90 \mathrm{~mm}$. Pada bagian ruas yang lain dibuat sistem sambungan yang lebih kuat menggunakan double pelat dan dua buah baut karena bagian ini tidak boleh gagal mendahului bagian ruas yang merupakan model sambungan yang akan diuji kekuatannya. Adapun model sambungan bambu celah berpengisi seperti 
terlihat pada Gambar 1 berikut ini. Masingmasing variasi jarak ujung dibuat 3 benda uji.

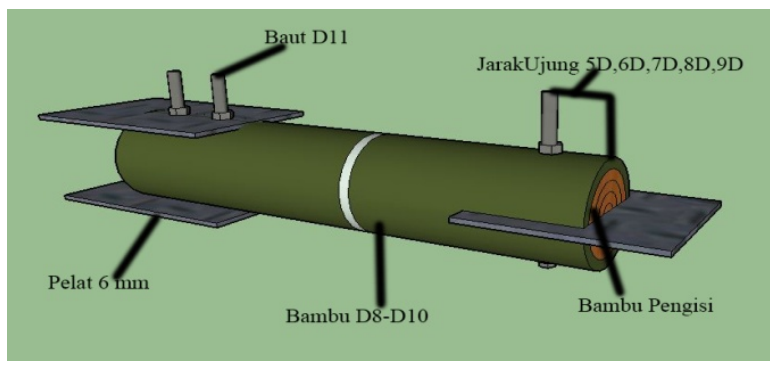

Gambar 1.Model sambungan bambu celah berpengisi

\section{Pengujiankuattariksambunganbambucelahber pengisi}

Pengujian dilaksanakan dengan menempatkan benda uji pada dudukannya yang ditempatkan pada rigid floor dan loading frame. Pembebanan benda uji menggunakan hydraulic jack yang dilengkapi load cell dan transducer indicator. Pertambahan sesaran sambungan dicek dengan menggunakan dial gauge. Pembebanan dilakukan dengan memompa hydraulic jack secara perlahan dan beban dibaca setiap kenaikan $10(x 10 \mathrm{lbs})$. Pengujian sambungan dilakukan sampai sambungan mengalami kegagalan yang ditandai dengan tidak bertambahnya beban pada pembacaan transducer indicatordan sesaran sambungan meningkat dengan cepat. Adapun setup pengujian benda uji seperti terlihat pada Gambar 2.berikut.

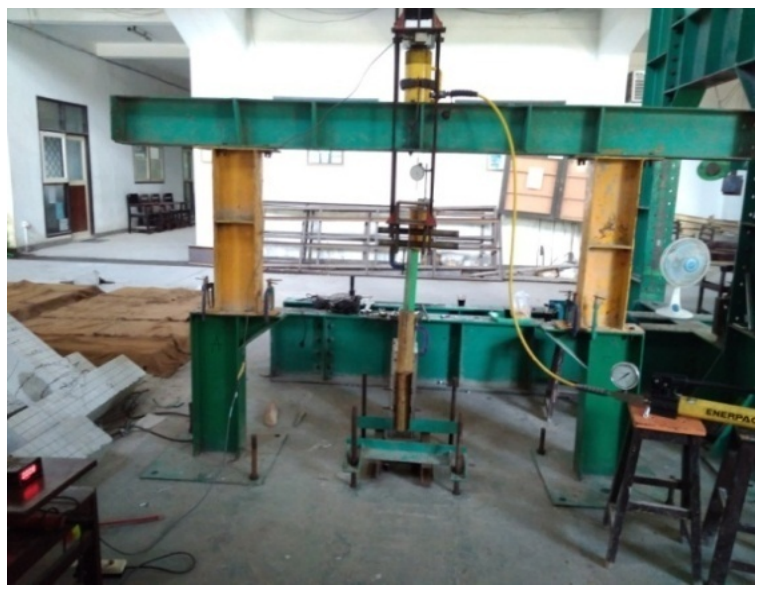

Gambar 2.Set-up pengujian
HASIL DAN PEMBAHASAN

\section{Pengujian Model Sambungan}

Pada penelitian ini kekuatan yang diambil untuk mengetahui pengaruh variasi jarak ujung adalah kekuatan pada saat sambungan mengalami kegagalan baik bamboo pecah, baut membengkok, maupun rekatan lepas. Adapun hasil pengujian kekuatan tarik sambungan maksimum rata-rata dapat dilihat pada Tabel 1 berikut.

Tabel 1.Hasil pengujian kuat tarik sambungan

\begin{tabular}{|c|c|c|c|}
\hline $\begin{array}{c}\text { Kode } \\
\text { Benda } \\
\text { Uji }\end{array}$ & $\begin{array}{l}\text { Beban maks } \\
\quad(\mathrm{kg})\end{array}$ & $\begin{array}{l}\text { Rerata } \\
(\mathrm{kg})\end{array}$ & $\begin{array}{c}\text { Prosentase } \\
\text { kenaikan }\end{array}$ \\
\hline \multirow{3}{*}{ J_50 } & 1564,92 & \multirow{3}{*}{1997,352} & \multirow{3}{*}{0} \\
\hline & 2168,21 & & \\
\hline & 2258,93 & & \\
\hline \multirow{3}{*}{ J_60 } & 1927,80 & \multirow{3}{*}{2124,36} & \multirow{3}{*}{6,36} \\
\hline & 2381,40 & & \\
\hline & 2063,88 & & \\
\hline \multirow{3}{*}{ J_70 } & 2290,68 & \multirow{3}{*}{2336,04} & \multirow{3}{*}{16,96} \\
\hline & 2290,68 & & \\
\hline & 2426,76 & & \\
\hline \multirow{3}{*}{ J_80 } & 2290,68 & \multirow{3}{*}{2381,40} & \multirow{3}{*}{19,23} \\
\hline & 2472,12 & & \\
\hline & 2381,40 & & \\
\hline \multirow{3}{*}{ J_90 } & 2517,48 & \multirow{3}{*}{2411,64} & \multirow{3}{*}{20,74} \\
\hline & 2336,04 & & \\
\hline & 2381,40 & & \\
\hline
\end{tabular}

Dari Tabel 1 diatas terlihat bahwa seiring dengan bertambah panjangnya jarak ujung sambungan menyebabkan kenaikan kuat tarik yang dihasilkan. Prosentase kenaikan kuat tarik dari jarak ujung terkecil ke jarak ujung terbesar berturut-turut berkisar sebesar $6 \%, 17 \%, 19 \%$, dan $21 \%$. Hasil penelitian ini sesuai dengan hasil penelitian Saputro [7] yang menunjukkan bahwa semakin besar jarak ujung alat sambung nilai daktilitasnya meningkat.

Untuk melihat hubungan yang lebih jelas antara kuat tarik rata-rata sambungan bambu celah berpengisi dengan besarnya jarak ujung maka dibuat dalam bentuk grafik seperti terlihat pada Gambar 3 berikut ini. 


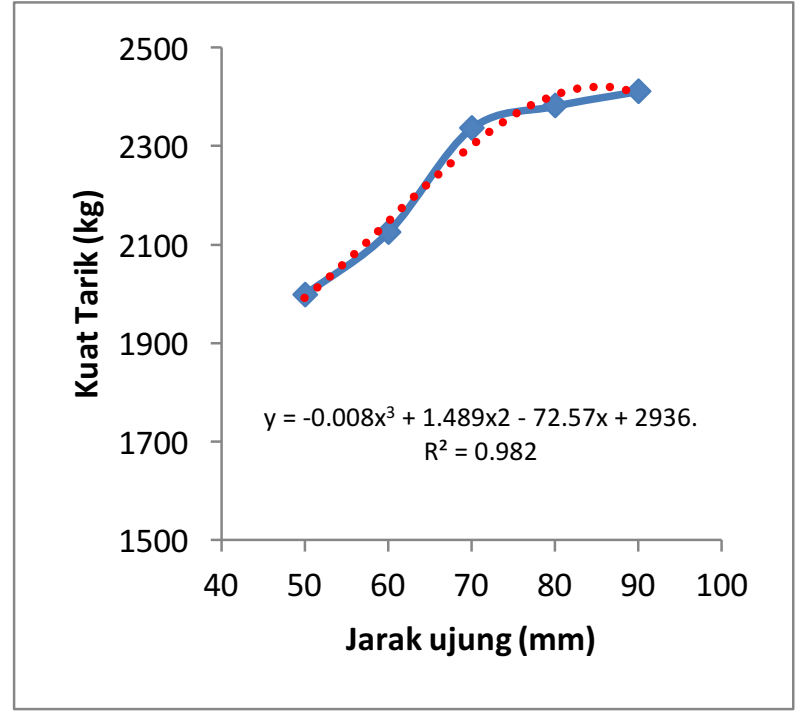

Gambar3. Grafik hubungan antara kuat tarik dan jarak ujung sambungan

Dari Gambar3. Terlihat bahwa tren kenaikan kuat tarik sambungan berbentuk polynomial dengan nilai $\mathrm{R}^{2}$ mendekati 1 (satu) $\left(\mathrm{R}^{2}=0,982\right)$. Hubungan antara kuat tarik dan jarak ujung dapat didekati dengan persamaan matematika seperti terlihat pada Persamaan 1.

$$
\begin{aligned}
& y=-0,008 x^{3}+1,489 x^{2}-72,57 x+2936 \ldots \\
& \text { dengan: } \quad \mathrm{y}=\text { kuat tarik }(\mathrm{kg}) \\
& \mathrm{x}=\text { jarak ujung }(\mathrm{mm})
\end{aligned}
$$

Dari tren hubungan di atas juga dapat dilihat bahwa pada jarak ujung antara $80 \mathrm{~mm}$ sampai dengan $90 \mathrm{~mm}$ terdapat nilai kuat tarik optimum dari sambungan bambu celah. Hal ini menunjukkan bahwa tidak selalu jarak ujung yang besar akan menghasilkan kuat tarik yang tinggi pula sebab kekuatan sambungan tidak hanya ditentukan oleh geometri sambungan (jarak ujung) tetapi juga ditentukan oleh jenis alat sambung baut (diameter, mutu, dan panjang). Jadi dengan bantuan Gambar 3 di atas dapat digunakan untuk memprediksi kekuatan tarik sambungan dengan berbagai variasi jarak ujung sampai kekuatan tarik optimumnya khusus untuk penggunaan baut berdiameter $10 \mathrm{~mm}$.

\section{Perbandingan Hasil Pengujian dengan Pengujian yang Pernah Dilakukan}

Penelitian tentang sambungan bambu berpengisi juga pernah dilakukan oleh Sugiartha [8] dan Marwansyah [4]. Pada penelitian Sugiartha [8] menggunakan pengisi dari kayu Ipil sedangkan Marwansyah [4] menggunakan pengisi dari bambu sisa yang sama dengan benda uji pada penelitian ini namun yang membedakan adalah kedua model sambungan yang dibuat di atas menggunakan double pelat buhul. Hasil yang dibandingkan adalah kuat tarik maksimum yang dihasilkan untuk masing-masing model. Untuk lebih jelasnya bisa dilihat pada Gambar 4 berikut.

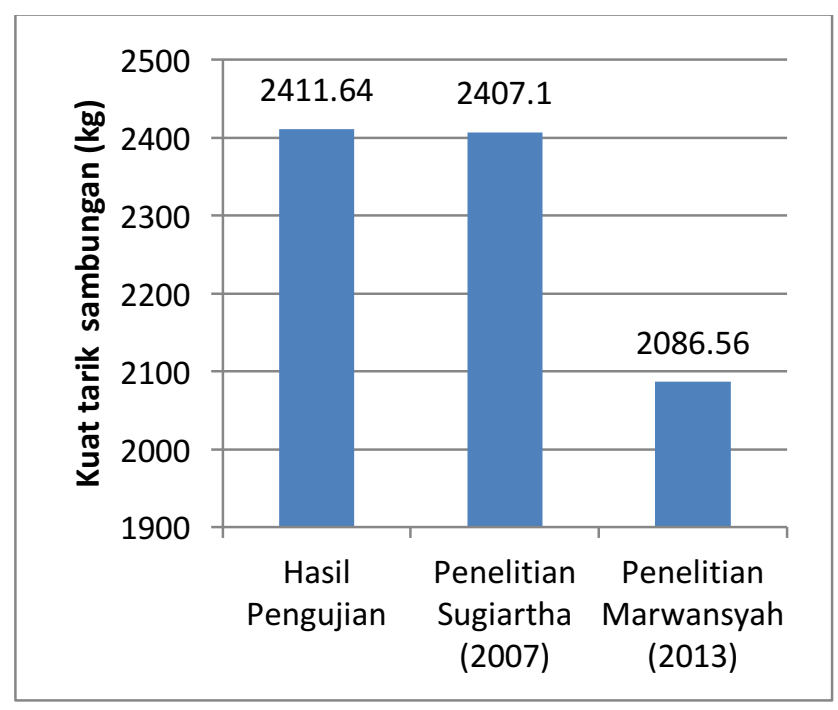

Gambar 4. Perbandingan hasil pengujian dengan penelitian terdahulu

Berdasarkan Gambar 4 dapat dilihat terjadinya perbedaan pada hasil pengujian dengan hasil pengujian Sugiartha [8] dan Marwansyah [4] namun tidak signifikan yaitu berkisar sebesar 0,2 $\%$ dan $15 \%$. Hasil pengujian pada penelitian ini menunjukkan hasil yang lebih besar dari hasil pengujian kedua penelitian terdahulu. Hal ini diduga disebabkan oleh beberapa faktor antara lain jenis bahan pengisi dan teknik pada saat pengempaan pada proses perekatan.

Jika dilihat lebih lanjut penggunaan bambu sisa untuk bahan pengisi rongga bambu menunjukkan kinerja yang baik tidak kalah dengan bahan pengisi dari kayu Ipil. Disamping itu juga model sambungan bambu celah yang hanya memanfaatkan satu pelat buhul baja dapat mengimbangi kekuatan tarik sambungan yang 
menggunakan double pelat buhul. Hal ini berarti model sambungan bambu celah dapat mereduksi berat total sistem sambungan pada struktur kudakuda tanpa mengurangi kekuatannya. Pengurangan penggunaan pelat buhul juga mengakibatkan pengurangan biaya sistem sambungan secara keseluruhan dengan kata lain biaya struktur kuda-kuda menjadi lebih ekonomis.

\section{Pola Kegagalan Sambungan}

Typikal pola kegagalan sambungan bambu celah berpengisi dengan variasi jarak ujung dapat dilihat pada Gambar 5 sampai dengan Gambar 9 di bawah ini.

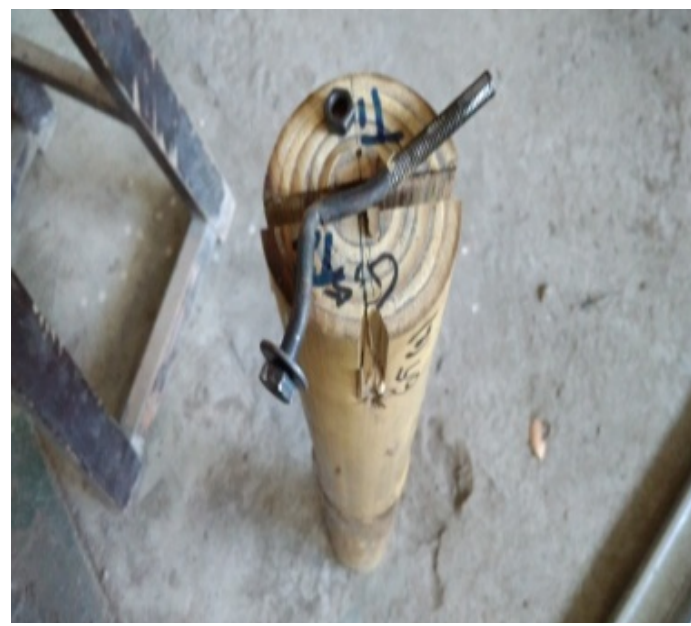

Gambar 5. Kegagalan pada jarak ujung 50mm

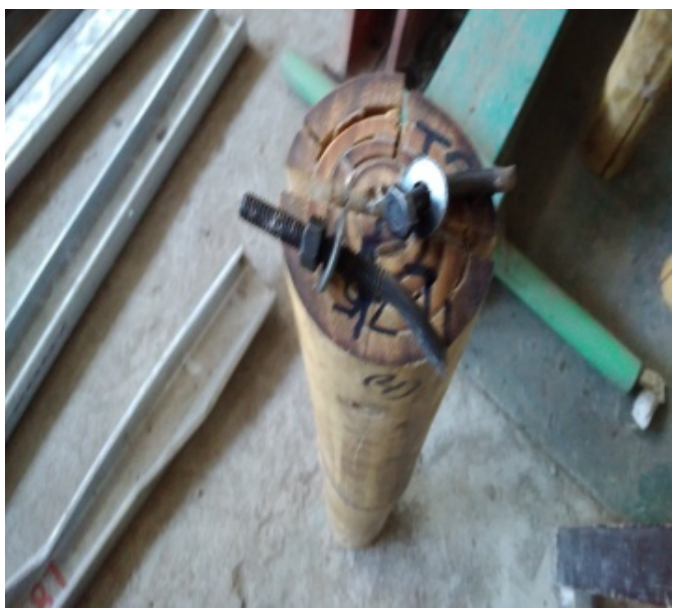

Gambar 6. Kegagalan pada jarak ujung $60 \mathrm{~mm}$

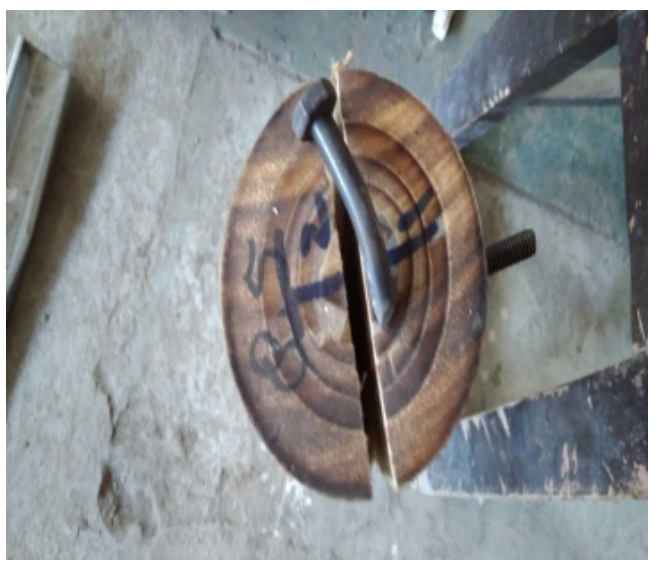

Gambar 7. Kegagalan pada jarak ujung 70mm

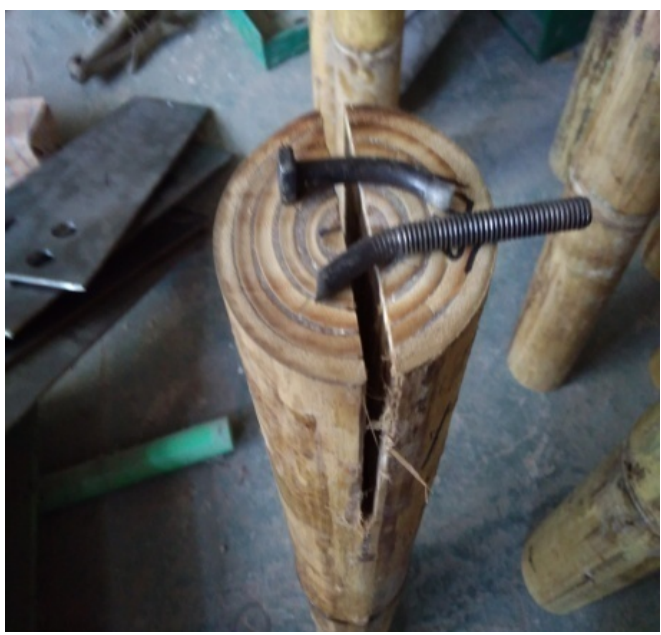

Gambar 8. Kegagalan pada jarak ujung $80 \mathrm{~mm}$

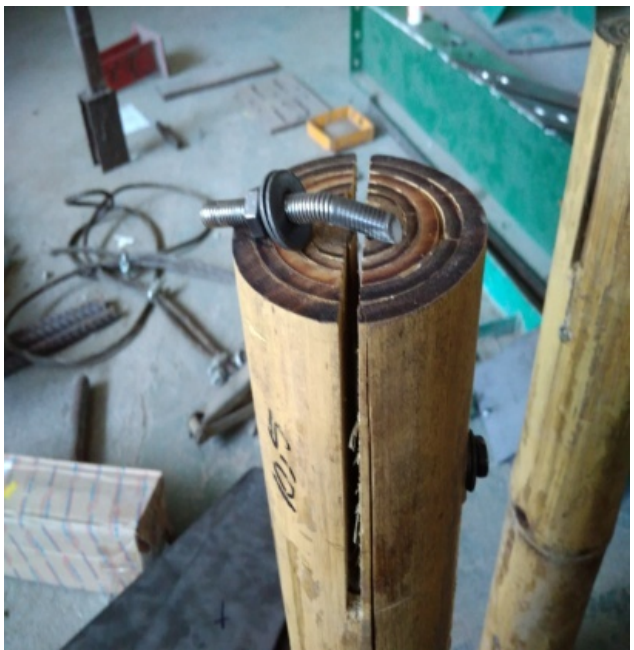

Gambar 9. Kegagalan pada jarak ujung 90mm 
Dari Gambar 5 sampai dengan Gambar 9 menunjukkan pola kegagalan yang terjadi pada kelima variasi benda uji tersebut relatif hampir sama. Secara visual pola kegagalan yang terjadi pada sambungan bambu celah berupa lelehnya baut yang ditandai dengan sesaran yang besar kemudian putusnya alat sambung baut. Pada keseluruhan benda uji terlihat bahwa rekatan bambu pengisi tidak ada yang terlepas meskipun ada dibeberapa bagian sudah mulai retak-retak khususnya di bagian tengah. Hal ini menunjukkan sistem komposit setempat pada bagian sambungan ini bekerja dengan baik. Lelehnya baut terjadi di tengah batang baut tepat pada daerah pembebanan memalui pelat buhul baja.

\section{KESIMPULAN DAN SARAN}

\section{Kesimpulan}

Kuat tarik sambungan meningkat seiring dengan meningkatnya panjang jarak ujung. Kuat tarik maksimum yang dihasilkan pada variasi jarak ujung50 mm, $60 \mathrm{~mm}, 70 \mathrm{~mm}, 80 \mathrm{~mm}$ dan $90 \mathrm{~mm}$ berturut-turut sebesar $1997,352 \mathrm{Kg}$, $2124,36 \mathrm{Kg}, 2336,04 \mathrm{Kg}, 2381,4 \mathrm{Kg}$, dan 2411,64 $\mathrm{Kg}$ dengan prosentase kenaikan berkisar sebesar 6 $\%, 17 \%$, $19 \%$, dan $21 \%$. Pola kegagalan yang terjadi pada seluruh benda uji relatif sama yaitu lelehnya baut yang ditandai dengan baut melengkung atau patah.

\section{Saran}

Sebelum proses pereketan, bagian permukaan yang akan direkatkan dibersihkan terlebih dahulukemudian dikasarkan dengan sikat kawat.Pada saat proses perekatan antara bambu dengan pengisinya harus dilakukan pengempaan yang maksimal agar perekatan berlangsung dengan baik.Perlu dilakukan penelitian lanjutan dengan memvariasikan jarak ujung yang lebih kecil dari 5D guna mendapatkan persyaratan minimum jarak ujung untuk sambungan bambu yang dapat digunakan untuk struktur rangka atap.

\section{UCAPAN TERIMA KASIH}

Penulis mengucapkan terima kasih yang sebesar-besarnya kepada Direktorat Jendral Penguatan Riset dan Pengembangan, Kementerian Riset, Teknologi dan Pendidikan Tinggi Republik Indonesia dan Jurusan Teknik Sipil Fakultas Teknik Universitas Mataram atas dukungan dana dan fasilitas laboratorium
DAFTAR PUSTAKA

[1] Awaludin, A., Dasar-dasar Perencanaan Sambungan Kayu,Biro Penerbit KMTS Jurusan Teknik Sipil FT UGM, Yogyakarta (2005)

[2] Bachtiar, G., Surjokusumo, S., Nugroho, N., dan Hadi, Y.S., "Perancangan Sambungan Bambu untuk Komponen Rangka Batang Ruang”, Forum Pascasarjana Vol. 31 No.1 Januari 2008:69-78

[3] Destisari, Y., Pengaruh Diameter Baut Pada Jarak Baut Ke Ujung Bambu Pada Sistem Sambungan Bambu,Artikel Ilmiah Fakultas Teknik, Universitas Gadjah Mada Yogyakarta (2016)

[4] Marwansyah., Pengaruh Variasi Volume Pengisi Terhadap Kuat Tarik Sambungan Bambu Dengan Alat Sambung Baut,Skripsi S1 Fakultas Teknik, Universitas Mataram (2013)

[5] Morisco and Mardjono, F., "Strength of Filled Bambu Joint" : In Rao, I.V.R., Shastry, C.B., Ganapathy, P.M., and Janssen, Bambu, People and the Environment, Vol.3, Engineering and Utilization, INBAR, EBF, Government of the Netherlands, IPGRI, IDRC.(1996),113-120.

[6] Morisco, Rekayasa Bambu, Nafiri Offset, Yogyakarta (1999)

[7] Saputro, D.N., "Tinjauan Jarak Ujung dan Jarak Antar Alat Sambung Baut Pada Kayu LVL Sengon (Paraserianthes falcaria)",Artikel Ilmiah Fakultas Teknik, Universitas Gadjah Mada Yogyakarta (2016)

[8] Sugiartha, I.W., "Pengaruh Variasi Kayu Pengisi Terhadap Kekuatan Tarik Sambungan Bambu dengan Alat Sambung Baut", Orisa Vol.3 No.3, Desember 2007:11-22 